\title{
IMPACT OF DOUBLING THE RECOMMENDED DOSE OF MAGICFORCE (LAMBDA-CYHALOTHRIN + DIMETHOATE) ON MAJOR ASSOCIATED ARTHROPODS AND PERFORMANCE OF WATERMELON
}

\author{
${ }^{1 *}$ Okrikata, E., ${ }^{1}$ Agere, H., ${ }^{2}$ Adepoju I.O. and ${ }^{3}$ Malu, S.P. \\ ${ }^{1}$ Department of Biological Sciences, Federal University, Wukari, Taraba State, Nigeria. \\ ${ }^{2}$ Department of Crop Production and Protection, Federal University, Wukari, Taraba State, Nigeria. \\ ${ }^{3}$ Department of Chemical Sciences, Federal University, Wukari, Taraba State, Nigeria. \\ "Corresponding author. E-mail address: eokrikata@gmail.com; okrikata@fuwukari.edu.ng
}

(Received: $22^{\text {nd }}$ December, 2020; Accepted: $23^{\text {rd }}$ February, 2021)

ABSTRACT

\begin{abstract}
Some crop growers hold the view that application of pesticides at higher than the manufacturer's recommended doses results in better pest control and crop productivity. The veracity of this perception was evaluated in field experiments at the experimental field of Federal University Wukari. A recommended insecticide and acaricide; Magicforce $^{\circledR}$ (Lambda-cyhalothrin 15g/L + Dimethoate $300 \mathrm{~g} / \mathrm{L}$ ) was evaluated against insect pests of watermelon (Citrullus lanatus Thunb.) and other associated beneficial arthropods. The experiments were laid in a Randomized Complete Block Design with five treatments (control inclusive). Data collected includes arthropod (pest and beneficial) densities, crop growth, and number of fruits at the early-fruiting stage which were analyzed using variance analysis after appropriate transformations. Student's t-test was used to compare early- and lateseason's variables while correlation and regression analyses were used to determine relationships between key variables. Results showed that plots treated with double the highest manufacturer's recommended dose of Magicforce $^{\circledR}$ (cost implication of $\$ 144,000$ ) had lower pest (leaf beetle species and Bactrocera cucurbitae) and beneficial arthropod (predatory ants, spiders and Apis mellifera) densities than those treated with the lowest (cost - 48,000 ) and highest (cost - 72,000) recommended doses. Their plant growth (vine length and number of leaves) and fruit production were however comparatively lower though largely statistically comparable. The relationship between the quantity of Magicforce ${ }^{\circledR}$ applied and number of fruits produced were though positive, only moderate and insignificant in both early- $\left(r=0.665, R^{2}=44.3 \%, p=0.220\right)$ and late- $\left(r=0.659, R^{2}=43.4 \%\right.$, $\mathrm{p}=0.227)$ crops. The results revealed that the application of double the manufacturer's recommended dose of Magicforce $^{\circledR}$ (with its comparatively higher cost implication of $100-200 \%$ ) suppressed growth of watermelon by $1.96-6.20 \%$, and impeded fruit production by $9.14-13.30 \%$. While there is need to verify the mechanism of this key finding, the need to source for genuine pesticides and follow manufacturer's recommended doses are highlighted.
\end{abstract}

Keywords: Arthropods, Insect pests, Organophosphate, Pesticide over-dose, Pyrethroid, Watermelon

\section{INTRODUCTION}

Watermelon (Citrullus lanatus'Thunb.) is adapted to a wide variety of agro-ecology and its consumption is greater than that of any other cucurbit in the world. In Nigeria, there is an increasing demand for it. This is largely due to the growing awareness of its nutritional, health and economic value (Reetu and Tomar, 2017; Okrikata et al., 2019a). As in many parts of the world, watermelon production has been shown to be suppressed by a complex of arthropods like aphids, leaf beetles, white flies, stinkbugs, crickets and millipedes with no growth stage exempted from infestation resulting in $30-100 \%$ yield losses (Shagufta, 2012; Okrikata and Ogunwolu, 2017; Okrikata et al., 2019a). Despite its importance vis-à-vis pest pressure, watermelon has attracted relatively little entomological (crop- pest interaction) research interest in Nigeria.

In a study conducted by Okrikata and Ogunwolu (2017) within the southern Guinea Savanna region of Nigeria, the report shows that the indiscriminate application of recommended synthetic insecticides, mainly belonging to the classes of organophosphates, pyrethroids and/or their combinations such as Best (Cypermethrin), Karate (Lambda-cyhalothrin), Magicforce ${ }^{\circledR}$ (Lambda-cyhalothrin + Dimethoate), Best Action (Cypermethrin + Dimethoate), and Attack (Pirimiphos-methyl + Permethrin) as prophylactics is the popular control method used by crop growers. The environmental, human health and monetary cost implication of misuse of synthetic pesticides are well documented (Kranthi et al., 2002; Jeyanthi and Kombairaju, 
2005; Lamichhane et al., 2016; Okrikata and Ogunwolu, 2019).

Underscoring the urgency for reducing pesticide usage, a current global record published by Boedeker et al. (2020) shows a whopping 385 million cases of acute unintended pesticide poisoning annually as against 25 million in 1990. Hence, in Europe, despite the strict regulatory and enforcement mechanisms, crop growers were directed to reduce pesticide usage. In France for example, there was a deliberate policy targeted at halving pesticide usage by 2018 (Glover-Amengor and Tetteh, 2008; Hossard et al., 2014). Same cannot be said of many developing countries (Nigeria inclusive) where weak coordination and monitoring of the agrochemical sector is triggering wrong use (mostly over dosage), and adulteration of pesticides; resulting in rising cases of pesticide resistance, environmental pollution and human health hazards (Jeyakumar and Gupta, 2002; Okrikata and Ogunwolu, 2019). It has been postulated that local farmers and even government or agency-trained personnel usually apply higher than the manufacuturer's recommended doses of pesticides on the perception that the recommended doses are not effective or that higher than the recommended doses effect rapid kill of target pests (Ojo, 2016; Nemade et al., 2017). Whether this practice and/or perception have any bearing with pesticide adulteration or the development of pesticide resistance is a matter of rigorous investigation.

Some two decades ago, a study conducted by Sabur and Molla (2001) revealed that more than $20 \%$ of farmers in Bangladesh applied insecticides at higher than the field recommended doses on their crops. Also, a study conducted by Kinuthia (2019) revealed that $97.7 \%$ of small scale tomato growers in Nakuru county of Kenya applied insecticide overdose. A similar finding was reported by Jallow et al. (2017) in Kuwait. In Nigeria, a study conducted by Oluwole and Cheke (2009) in Ekiti State showed that $94.7 \%$ of crop growers apply a mixture of 2 or more pesticides without reference to the pesticide labels nor concerned about their compatibility. Pesticide overapplication (in doses and frequencies) on fruit-vegetables, particularly watermelon, with a resultant accumulation of higher than acceptable pesticide residues in the ready to eat fruits are well reported in Nigeria (Akan et al., 2015; Mahmud et al., 2015; Okrikata and Ogunwolu, 2017; Omoyajowo et al., 2018).

Pesticide use in most developing nations is officially and primarily based on the manufacturer's recommended doses usually written on the pesticide container's label. Though helpful, the recommended doses may not be appropriate under local conditions since they may have been tried/evaluated under different sociocultural and agro-climatic conditions (GloverAmengor and Tetteh, 2008). As such, a critical question to ask is: how does pesticide overdose affect the bionomics of beneficial arthropods in our agro-climate? This need to be investigated as information therefrom could be useful for farmers' education. While some studies had looked at effects of insecticide overapplication on soil microbial environment and biochemistry (Meena et al., 2020), researches which tests the impact of overapplication of commonly used insecticides on above-ground arthropods (pest and beneficials) and productivity of crops, particularly watermelon, are hard to find - there are obvious dearth of information on this in Nigeria. This study therefore examines the impact of double application of manufacturer's recommended doses of Magicforce ${ }^{\circledR}$ (Lambdacyhalothrin $15 \mathrm{~g} / \mathrm{L}+$ Dimethoate $300 \mathrm{~g} / \mathrm{L}$ ) on arthropods (pest and beneficials), its cost implication and effect on fruiting of watermelon in an area within the southern Guinea Savanna region of Nigeria. Findings from this study will provide a homegrown data of the impact of 'inappropriate pesticide application' on pest density and crop performance which are indicators of primary concern to crop growers.

\section{MATERIALS AND METHODS \\ Description of the Study Site}

The study was conducted on the experimental field of Federal University, Wukari, Nigeria (N7 50 '37", E9 ${ }^{\circ} 46^{\prime} 31^{\prime \prime}$ coordinates; 187 m altitude) which lies within the southern Guinea Savanna region. The area is characterized by a warm tropical climate, distinct rainy (commencing in April and ending in October with peaks in June and September) and dry season. The mean annual temperature and rainfall is $26.8^{\circ} \mathrm{C}$ and $1205 \mathrm{~mm}$, 
respectively (Okrikata et al., 2019b).

\section{Field Layout and Experimental Design}

Watermelon (var. Sweet Sangria $F_{1}$ ) was sown in 20 plots $(5 \times 8 \mathrm{~m})$ on a ploughed and harrowed land during the early- and late-cropping seasons of 2020 (sowing dates: $23^{\text {rd }}$ April and $25^{\text {th }}$ August, respectively). The plots were grouped into 4 replications of 5 treatments in a Randomized Complete Block Design (RCBD).

The treatments were applications of a widely used broad spectrum recommended systemic, contact and stomach insecticide and acaricide with repellent properties and residual activity of up to 1 month: Magicforce ${ }^{\circledR}$ (Lambda-cyhalothrin 15g/L + Dimethoate $300 \mathrm{~g} / \mathrm{L}$ ) [Manufactured by Anhui Zhongshen Chemical Industries Co. Ltd., China and distributed by Jubaili AGROTEC Ltd., Kano, Nigeria] applied at $400 \mathrm{Lha}^{-1}$ spray output with the aid of 8-litre capacity Maxipro sprayer at the following rates:

i. Highest Field Recommended dose (HFRD) - $1.5 \mathrm{Lha}^{-1}$ (30 ml/8 L sprayer),

ii. Lowest Field Recommended dose (LFRD) $-1 \mathrm{Lha}^{-1}(20 \mathrm{ml} / 8 \mathrm{~L}$ sprayer),

iii. Twice Highest Field Recommended dose (2x HFRD) $-3 \mathrm{Lha}^{-1}$ ( $60 \mathrm{ml} / 8 \mathrm{~L}$ sprayer $)$,

iv. Half Lowest Field Recommended dose $(1 / 2 \mathrm{LFRD})-0.5 \mathrm{Lha}^{-1}(10 \mathrm{ml} / 8 \mathrm{~L}$ sprayer $)$, v. Control (CT) - no spray.

Spraying commenced at 50\% emergence stage and proceeded weekly (between 16:00 - 18:00 h) until early fruiting stage (a total of 8 sprays) when the experiment was terminated. All the plots were treated with Zeb-care ${ }^{\circledR}$ (Mancozeb 80\% WP.) as a preventive contact fungicide at the rate of $2 \mathrm{kgha}^{-1}$ at the vegetative and flowering stages. NPK (20:10:10) fertilizer was applied at the rate of 200 $\mathrm{kg} / \mathrm{ha}$ at 3 weeks after planting (WAP) using the side band method. Manual weeding was done when necessary and the field left to natural arthropod infestation.

\section{Data Collection}

\section{Arthropod sampling}

Arthropods were predominated by leaf beetles [Aulacophora africana (Weise), Asbecesta nigripennis
(Weise), Asbecesta transversa (Allard), Monolepta nigeriae (Bryant) - Chrysomelidae, Epilachna chrysomelina (Fabricius) - Coccinellidae], Apis mellifera (L.) [Hymenoptera: Apidae], predatory ants (mainly Camponotus sp., Crematogaster sp., Pheidole sp.) and spiders. They were sampled using a portable generator (Tiger TG950DC) powered modified Grizzly 2500/8 leaf blower-vac (Grizzly Gartengeräte $\mathrm{GmbH} \&$ Co. KG, China) with a 5 $\mathrm{cm}$ internal diameter inlet cone (Agere et al., 2021) swept through $5 \mathrm{~m}$ length of the middle row of each plot at a walking speed of $\approx 1 \mathrm{~m} / \mathrm{sec}$. between $0600-0800 \mathrm{~h}$. Predominant arthropods were collected following the method described by Agere et al. (2021), sorted and preserved in 70\% alcohol for counting and mean populations were expressed as number $( \pm \mathrm{SE}) / 5 \mathrm{~m}$ length of row.

Bactrocera cucurbitae (Coquillett) [Diptera: Tephritidae] infestation was assessed during the early fruiting stage in which case infested fruits were identified and counted in each plot. They were then harvested per plot, split open and the number of B. cucurbitae larvae in them counted and expressed as number $( \pm \mathrm{SE})$ per fruit using the formula described by Barma et al. (2013):

No. of B.cucurbitae larvae per fruit $=$

No. of infested fruits per plot $x$ No. of larvae per infested fruits No. of fruits per plot

\section{Assessment of Leaf Injury and Growth Indices}

The proportion and severity of leaves injured were computed from randomly selected leaves (10 leaves/plot) at 50\% vegetative, $50 \%$ flowering, and $50 \%$ fruiting stages and pooled using the method described by Okrikata and Anaso (2008) and Okrikata et al. (2020) wherein leaves were scaled $0-4$ for severity of injury:

$$
\begin{aligned}
& 0 \text { ( } 0 \% \text { leaf injury), } \\
& 1 \text { (1-25\% leaf injury), } \\
& 2 \text { (26-50\% leaf injury), } \\
& 3 \text { (51-75\% leaf injury), } \\
& 4 \text { ( } 76-100 \% \text { leaf injury). }
\end{aligned}
$$

Scores obtained per plot were then converted to Attack severity (\%) by the equation;

Attack severity $(\%)=\sum \mathrm{xn} 100 / \mathrm{Nx} 4$ 
Where: $\Sigma \mathrm{n}=$ summation of individual injury scores/plot, $\mathrm{N}=$ number of scores taken/plot $(=10)$, and

$4=$ highest score on the scale.

At 6 weeks after emergence (WAE), 3 plants were selected randomly per plot and tagged, and from these, the main vine length $(\mathrm{cm})$ was assessed with the aid of a flexible tape and the number of leaves per plant also computed.

\section{Survival Rate Assessment and Yield Parameter}

The survival rate (SR) was computed as;

$S R(\%)=\quad \frac{\text { No.of plants reaching maturity }}{\text { No. of plants per plot at } 10 \text { days after planting }}$

The yield parameter computed was the number of fruits at the early fruiting stage per treatment and from this, the proportion of fruits damaged (cracked, misshapen, discolored, insect damaged, and/or infected by blossom end rot) was also computed.

\section{Data Analysis}

Data collected were subjected to one way Analysis of Variance (ANOVA) and significantly different treatment means were separated by Student Newman Keul's (SNK) test at 5\% level of probability. However, in order to normalize the data collected and to meet the assumptions of parametric tests, count data were subjected to square root transformation while proportions were $\log$ transformed before variance analysis. Variables from the early- and late-seasons' trials were compared using two-tailed paired student's ttest while relationships between key variables were computed with correlation and linear regression analyses. Analyses were all conducted with IBM SPSS Statistics version 25.0 (SPSS Inc., Chicago, Illinois). The cost implication of each insecticide (Magicforce $^{\mathbb{B}}$ ) treatment was also computed and presented in $\mathrm{Nha}^{-1}$.

\section{RESULTS}

Quantity and Cost of Different Doses of Magicforce ${ }^{\circledR}$ Applied on Watermelon Plots

Table 1 shows that there were a total of 8 sprays for each of the treatments except for control that was not sprayed. Plots sprayed with $2 x$ HFRD received $24 \mathrm{~L}$ of Magicforce $^{\circledR} /$ ha with a cost implication of 144,000. Plots treated with HFRD got $12 \mathrm{~L}$ at 72,000 . Values for LFRD and $1 / 2$ LFRD were $8 \mathrm{~L}$ at 48,000 and $4 \mathrm{~L}$ at N24,000, respectively.

Table 1: Cost Implication of the Different Doses of Magicforce ${ }^{\circledR}$ Applied on Watermelon at Wukari in 2020

\begin{tabular}{lccc}
\hline Treatment & Total spray & $\begin{array}{c}\text { Total litres of } \\
\text { Magicforce }^{\circledR} \text { applied /ha }\end{array}$ & $\begin{array}{c}\text { Cost of Magicforce } \\
\text { used ( } \text { (ha }^{-1} \text { ) }\end{array}$ \\
\hline HFRD & 8 & 12 & 72,000 \\
LFRD & 8 & 8 & 48,000 \\
2x HFRD & 8 & 24 & 144,000 \\
1/2 LFRD & 8 & 4 & 24,000 \\
CT & - & - & - \\
\hline
\end{tabular}

HFRD - Highest Field Recommended Dose of Magicforce ${ }^{\circledR}$ for watermelon; LFRD - Lowest Field Recommended Dose of Magicforce ${ }^{\circledR}$ for watermelon; CT - Control (no spray); HFRD - 1.5L/ha (60ml/16L sprayer) for each spray; LFRD 1L/ha (40ml/16 L sprayer) for each spray; Prevailing Market price of a litre of Magicforce ${ }^{\circledR}$ - $\$ 6000$; United States Dollar (US\$) to Nigerian Naira ( exchange rate during the study period-US $\$ 381.20$ to $\$ 1$.

Impact of Different Doses of Magicforce ${ }^{\circledR}$ on Key Arthropods Associated with Watermelon Among the insecticide treatments and in both seasons, the least leaf beetle and B. cucurbitae infestations was observed in crops treated with $2 \mathrm{x}$ HFRD. However, statistical analysis revealed that
HFRD and LFRD were at par with 2x HFRD in the infestation rates except on the early-sown crop in which B. cucurbitae larvae/fruit in 2x HFRD treated plots was significantly $(\mathrm{p}<0.01)$ fewer (by $34.7 \%$ ) than those in LFRD. Overall, untreated (control) plots had significantly $(p<0.01)$ more 
leaf beetles - 1.8 to 8.7 -fold. Corresponding values for B. cucurbitae larvae/fruit was 1.7 to 10.7 -fold (Table 2).

Table 3 shows that the key beneficial arthropods associated with watermelon in the study area were predatory ants (Camponotus sp., Crematogaster sp. and Pheidole sp.), spiders, and bees (A. mellifera). Significantly $(\mathrm{p}<0.01)$ fewer and statistically comparable predatory ants were recorded in plots treated with HFRD and 2x HFRD in both seasons. Conversely, unsprayed plots and those sprayed with $1 / 2$ LFRD had more predatory ants which however do not differ significantly from those recorded in plots treated with LFRD.

In both seasons, unsprayed plots had significantly $(\mathrm{p}<0.01)$ the highest density of spiders
$(4.90 \pm 0.27$ and $5.20 \pm 0.24 / 5 \mathrm{~m}$ row in the earlyand late-sown crops, respectively) followed by plots treated with $1 / 2$ LFRD. The least density was recorded in plots treated with $2 \mathrm{x}$ HFRD $(1.63 \pm 0.28$ and $1.83 \pm 0.05 / 5 \mathrm{~m}$ row in the earlyand late-sown crops, respectively) which was statistically comparable with observations in HFRD and LFRD treated plots (Table 3).

Table 3 also shows that the number of $A$. mellifera $/ 5 \mathrm{~m}$ length row of plot in both seasons were least $(p<0.01)$ in plots treated with $2 x$ HFRD and highest in plots treated with LFRD. Density of $A$. mellifera in $1 / 2$ LFRD treated plots was however statistically comparable with those in HFRD and LFRD treated plots in the early-sown crops and with only HFRD treated plots in the late-sown crops.

Table 2: Effect of Varying Doses of Magicforce ${ }^{\circledR}$ on key Pests Associated with Early- and Late-sown Watermelon at Wukari in 2020

\begin{tabular}{|c|c|c|c|c|}
\hline \multirow[b]{2}{*}{ Treatment } & \multicolumn{2}{|c|}{ Early-sown } & \multicolumn{2}{|c|}{ Late-sown } \\
\hline & Leaf beetles $/ 5 \mathrm{~m}$ length of row ${ }^{*}$ & $\begin{array}{l}\text { B. cucurbitae } \\
\text { larvae/fruit }\end{array}$ & Leaf beetles $/ 5 \mathrm{~m}$ length of row & $\begin{array}{l}\text { B. c ucurbitae } \\
\text { larvae/fruit }\end{array}$ \\
\hline HFRD & $1.10 \pm 0.18\left(1.04 \pm 0.09^{c}\right)$ & $0.95 \pm 0.05\left(0.97 \pm 0.03^{\mathrm{cd}}\right)$ & $1.90 \pm 0.14\left(1.38 \pm 0.05^{c}\right)$ & $0.70 \pm 0.11\left(0.82 \pm 0.13^{c}\right)$ \\
\hline LFRD & $1.53 \pm 0.28\left(1.23 \pm 0.06^{c}\right)$ & $1.15 \pm 0.10\left(1.07 \pm 0.05^{c}\right)$ & $2.10 \pm 0.24(1.45 \pm 0.04 c)$ & $0.85 \pm 0.12(0.91 \pm 0.07 c)$ \\
\hline 2x HFRD & $1.08 \pm 0.24\left(1.02 \pm 0.11^{c}\right)$ & $0.75 \pm 0.06\left(0.86 \pm 0.04^{d}\right)$ & $1.80 \pm 0.12\left(1.34 \pm 0.02^{c}\right)$ & $0.55 \pm 0.19(0.73 \pm 0.07 c)$ \\
\hline $1 / 2$ LFRD & $5.28 \pm 0.24\left(2.29 \pm 0.05^{b}\right)$ & $3.70 \pm 0.11\left(1.92 \pm 0.03^{b}\right)$ & $6.35 \pm 0.42\left(2.52 \pm 0.08^{b}\right)$ & $3.53 \pm 0.21\left(1.88 \pm 0.06^{b}\right)$ \\
\hline $\mathrm{CT}$ & $9.40 \pm 0.59\left(3.06 \pm 0.10^{\mathrm{a}}\right)$ & $6.43 \pm 0.31\left(2.53 \pm 0.06^{\mathrm{a}}\right)$ & $11.39 \pm 0.53\left(3.37 \pm 0.08^{\mathrm{a}}\right)$ & $5.88 \pm 0.52\left(2.42 \pm 0.05^{\mathrm{a}}\right)$ \\
\hline P-value & $<0.01$ & $<0.01$ & $<0.01$ & $<0.01$ \\
\hline
\end{tabular}

Figures in parentheses are square root transformed values; HFRD $=$ Highest Field Recommended Dose of Magicforce ${ }^{\circledR}$ for watermelon; LFRD = Lowest Field Recommended Dose of Magicforce ${ }^{\circledR}$ for watermelon; CT $=$ Control (no spray). Means $( \pm \mathrm{SE})$ are values of 4 replications and means $( \pm \mathrm{SE})$ followed by the same superscript letter(s) within a column are not significantly different using Student-Newman Keul's $(\mathrm{SNK})$ test $(\mathrm{p} \leq 0.05)$. "Leaf beetles (mean of $A$. africana, A. nigripennis, A. transversa, M. nigeriae and E. chrysomelina).

Table 3: Effect of Varying Doses of Magicforce ${ }^{\circledR}$ on key Beneficial Arthropods Associated with Early- and Latesown Watermelon at Wukari in 2020

\begin{tabular}{|c|c|c|c|}
\hline Treatment & Predatory ants $/ 5 \mathrm{~m}$ length of row & Spiders / $5 \mathrm{~m}$ length of row $^{b}$ & A. mellifera /5 $\mathrm{m}$ length of row \\
\hline \multicolumn{4}{|l|}{ Early-sown } \\
\hline HFRD & $2.83 \pm 0.03(1.68 \pm 0.01 b)$ & $1.43 \pm 0.29(1.18 \pm 0.11 \mathrm{c})$ & $3.60 \pm 0.07\left(1.90 \pm 0.02^{a}\right)$ \\
\hline LFRD & $3.43 \pm 0.15\left(1.85 \pm 0.04^{\mathrm{ab}}\right)$ & $1.98 \pm 0.30\left(1.39 \pm 0.12^{c}\right)$ & $3.83 \pm 0.05\left(1.96 \pm 0.01^{a}\right)$ \\
\hline 2x HFRD & $2.68 \pm 0.24(1.63 \pm 0.07 b)$ & $1.63 \pm 0.28\left(1.26 \pm 0.10^{c}\right)$ & $2.08 \pm 0.09\left(1.44 \pm 0.03^{c}\right)$ \\
\hline 1/2 LFRD & $4.03 \pm 0.37\left(2.00 \pm 0.09^{a}\right)$ & $3.65 \pm 0.10\left(1.91 \pm 0.02^{b}\right)$ & $3.50 \pm 0.14\left(1.87 \pm 0.04^{a}\right)$ \\
\hline CT & $3.95 \pm 0.27(1.98 \pm 0.07 a)$ & $4.90 \pm 0.27\left(2.21 \pm 0.06^{a}\right)$ & $2.88 \pm 0.03\left(1.70 \pm 0.01^{b}\right)$ \\
\hline P-value & $<0.01$ & $<0.01$ & $<0.01$ \\
\hline \multicolumn{4}{|l|}{ Late-sown } \\
\hline HFRD & $3.15 \pm 0.10\left(1.77 \pm 0.29^{b}\right)$ & $1.98 \pm 0.28\left(1.40 \pm 0.09^{c}\right)$ & $3.20 \pm 0.11\left(1.79 \pm 0.03^{b}\right)$ \\
\hline LFRD & $3.88 \pm 0.10\left(1.97 \pm 0.26^{a}\right)$ & $2.50 \pm 0.33\left(1.57 \pm 0.11^{\mathrm{c}}\right)$ & $3.53 \pm 0.09\left(1.88 \pm 0.02^{a}\right)$ \\
\hline 2x HFRD & $3.13 \pm 0.26\left(1.76 \pm 0.07^{b}\right)$ & $1.83 \pm 0.05\left(1.35 \pm 0.02^{\mathrm{c}}\right)$ & $1.78 \pm 0.11\left(1.33 \pm 0.04^{\mathrm{d}}\right)$ \\
\hline 1/2 LFRD & $4.08 \pm 0.11\left(2.02 \pm 0.03^{a}\right)$ & $3.55 \pm 0.24\left(1.88 \pm 0.06^{b}\right)$ & $3.07 \pm 0.01\left(1.75 \pm 0.00^{b}\right)$ \\
\hline CT & $4.45 \pm 0.26\left(2.11 \pm 0.06^{a}\right)$ & $5.20 \pm 0.24\left(2.28 \pm 0.05^{a}\right)$ & $2.58 \pm 0.05\left(1.60 \pm 0.01^{c}\right)$ \\
\hline P-value & $<0.01$ & $<0.01$ & $<0.01$ \\
\hline
\end{tabular}

Figures in parentheses are square root transformed values; HFRD = Highest Field Recommended Dose of Magicforce ${ }^{\circledR}$ for watermelon; LFRD = Lowest Field Recommended Dose of Magicforce ${ }^{\circledR}$ for watermelon; CT = Control (no spray); Means $( \pm \mathrm{SE})$ are values of 4 replications. Means $( \pm \mathrm{SE})$ followed by the same superscript letter(s) within a column are not significantly different using Student-Newman Keul's (SNK) test $(\mathrm{p} \leq 0.05)$. ${ }^{\mathrm{a}}$ Predatory ants (mean of Camponotus sp., Crematogastersp. and Pheidole sp.); ${ }^{\mathrm{b}}$ Spider species were treated as a single population/taxon. 
Impact of Different Doses of Magicforce ${ }^{\circledR}$ on Leaf Damage, Growth Indices and Yield Parameters of Watermelon

Table 4 shows that overall, crops in control (unsprayed) plots had 1.65 to 6.22-fold more proportion of leaves injured and 1.65 to 19.26fold more severity of leaf injury (\%) than crops in treated plots. The least proportion of leaves injured was observed in crops treated with $2 \mathrm{x}$ HFRD which significantly did not differ from those observed in crops that received HFRD and LFRD treatments in both seasons.

Table 4 also shows that the severity of leaf injury $(\%)$ was lowest $(\mathrm{p}<0.01)$ in crops in $2 x$ HFRD treated plots $(1.79 \pm 0.19$ and $2.31 \pm 0.62$ in earlyand late-sown crops, respectively). This was followed by crops in HFRD treated plots (3.15 \pm 0.04 and $3.93 \pm 0.15$ in early- and late-sown crops, respectively). Both were statistically at par with crops in LFRD treated plots. Unsprayed plots had significantly $(\mathrm{p}<0.01)$ the highest severity of leaf injury (34.49 \pm 1.37 and $38.69 \pm 1.27$ in early- and late-sown crops, respectively).

Table 4 further shows that among the insecticide treatments, crops in HFRD treated plots had the longest main vine length $(\mathrm{cm})$ and number of leaves/plant at 6 weeks after emergence but statistically comparable with LFRD and 2x HFRD in both seasons. Among the insecticide treatments, crops in plots treated with $1 / 2$ LFRD had the shortest mean vine length and number of leaves in both seasons. Overall, the shortest mean vine length and number of leaves was observed in crops in unsprayed plots (37.07 to 55.45\% lesser main vine length and 53.55 to $74.63 \%$ lesser number of leaves/plant) than in the treated plots.

Table 5 shows that $<50 \%$ of plants reached maturity without insecticide intervention. It also shows that about $57-65 \%$ of crops that received $1 / 2$ LFRD treatment reached maturity. Survival rate $(\%)$ in HFRD, LFRD and 2x HFRD treated crops were $>80 \%$ and were statistically comparable in both the early- and late-sown crops. The results also shows that in both seasons, crops in HFRD treated plots produced the highest number of fruits followed by LFRD treated plots both of which were statistically comparable with $2 \mathrm{x}$ HFRD in the late- but not in the early-sown crops. The unsprayed plots had the fewest number of fruits per hectare (1367.98 \pm 179.49 for early- and $1297.98 \pm 174.96$ for late-crops). Damaged fruits $(\%)$ were least $(3.30 \pm 0.18$ and $4.30 \pm 0.18$ in the early- and late-crops, respectively) in crops from 2x HFRD treated plots which was statistically at par with that of HFRD and LFRD treated plots in the late-sown crops and only with HFRD treated plots in the early-crops. The proportions of damaged fruits in the unsprayed plots were $\approx 2$ to $20 x$ higher than those of treated plots in the earlysown crops and 2 to $17 \mathrm{x}$ higher in the late-crops (Table 5). 
Table 4: Effect of Varying Doses of Magicforce ${ }^{\circledR}$ on Leaf Damage and Growth Indices in Early- and Late-sown Watermelon at Wukari in 2020

\begin{tabular}{|c|c|c|c|c|}
\hline \multirow[b]{2}{*}{ Treatment } & \multicolumn{2}{|c|}{ Leaf damage } & \multicolumn{2}{|c|}{ Growth indices } \\
\hline & $\begin{array}{c}\text { Proportion of leaves } \\
\text { injured (\%) }\end{array}$ & $\begin{array}{c}\text { Severity of leaves injured } \\
(\%)\end{array}$ & $\begin{array}{l}\text { Main vine length at } \\
6 \text { WAE }(\mathrm{cm})\end{array}$ & $\begin{array}{c}\text { Number of leaves/plant } \\
\text { at } 6 \text { WAE }\end{array}$ \\
\hline \multicolumn{5}{|l|}{ Early-sown } \\
\hline HFRD & $8.34 \pm 2.89\left(1.95 \pm 0.33^{\mathrm{b}}\right)$ & $3.15 \pm 0.04\left(1.15 \pm 0.01^{c}\right)$ & $213.85 \pm 1.22\left(5.37 \pm 0.01^{\mathrm{a}}\right)$ & $96.50 \pm 2.31\left(9.82 \pm 0.12^{\mathrm{a}}\right)$ \\
\hline LFRD & $10.00 \pm 1.36\left(2.27 \pm 0.14^{b}\right)$ & $3.71 \pm 0.20\left(1.31 \pm 0.05^{c}\right)$ & $208.88 \pm 1.86\left(5.34 \pm 0.01^{\mathrm{ab}}\right)$ & $93.53 \pm 2.22\left(9.67 \pm 0.11^{a}\right)$ \\
\hline 2x HFRD & $7.50 \pm 2.10\left(1.90 \pm 0.28^{\mathrm{b}}\right)$ & $1.79 \pm 0.19\left(0.56 \pm 0.12^{\mathrm{d}}\right)$ & $204.78 \pm 1.93\left(5.32 \pm 0.01^{b}\right)$ & $91.03 \pm 1.08\left(9.54 \pm 0.06^{\mathrm{a}}\right)$ \\
\hline $1 / 2$ LFRD & $28.33 \pm 1.67\left(3.34 \pm 0.06^{a}\right)$ & $20.85 \pm 0.76\left(3.04 \pm 0.04^{b}\right)$ & $162.18 \pm 5.79(5.09 \pm 0.04)$ & $62.80 \pm 1.58\left(7.92 \pm 0.10^{\mathrm{b}}\right)$ \\
\hline СТ & $46.67 \pm 7.07\left(3.80 \pm 0.18^{a}\right)$ & $34.49 \pm 1.37\left(3.54 \pm 0.04^{\mathrm{a}}\right)$ & $96.50 \pm 1.48\left(4.57 \pm 0.02^{c}\right)$ & $24.48 \pm 0.69(4.95 \pm 0.07 c)$ \\
\hline P-value & $<0.01$ & $<0.01$ & $<0.01$ & $<0.01$ \\
\hline \multicolumn{5}{|l|}{ Late-sown } \\
\hline HFRD & $11.67 \pm 2.15(2.40 \pm 0.20 c)$ & $3.93 \pm 0.15(1.37 \pm 0.04 c)$ & $210.10 \pm 0.89\left(5.35 \pm 0.00^{a}\right)$ & $95.02 \pm 1.87\left(9.75 \pm 0.10^{a}\right)$ \\
\hline LFRD & $12.50 \pm 0.83(2.52 \pm 0.07 c)$ & $4.09 \pm 0.34(1.40 \pm 0.08 c)$ & $204.95 \pm 1.72\left(5.32 \pm 0.01^{a}\right)$ & $92.48 \pm 2.32\left(9.61 \pm 0.12^{a}\right)$ \\
\hline 2x HFRD & $10.83 \pm 1.59(2.35 \pm 0.16 c)$ & $2.31 \pm 0.62\left(0.81 \pm 0.14^{d}\right)$ & $200.83 \pm 2.04\left(5.30 \pm 0.01^{a}\right)$ & $89.13 \pm 1.22(9.44 \pm 0.07 a)$ \\
\hline $1 / 2$ LFRD & $35.84 \pm 2.10\left(3.57 \pm 0.06^{b}\right)$ & $21.45 \pm 0.60\left(3.06 \pm 0.03^{b}\right)$ & $148.73 \pm 2.03\left(5.00 \pm 0.02^{b}\right)$ & $60.43 \pm 1.79\left(7.77 \pm 0.12^{b}\right)$ \\
\hline CT & $59.17 \pm 7.86\left(4.04 \pm 0.05^{\mathrm{a}}\right)$ & $38.69 \pm 1.27(3.65 \pm 0.07 \mathrm{a})$ & $93.60 \pm 2.46(4.54 \pm 0.03 c)$ & $28.07 \pm 6.02\left(5.21 \pm 0.52^{c}\right)$ \\
\hline P-value & $<0.01$ & $<0.01$ & $<0.01$ & $<0.01$ \\
\hline
\end{tabular}

Figures in parentheses are logarithmic transformed values except, those of number of leaves/plant which is square root transformed; WAE = Weeks after emergence; HFRD = Highest Field Recommended Dose of Magicforce ${ }^{\circledR}$ for watermelon; LFRD = Lowest Field Recommended Dose of Magicforce ${ }^{\circledR}$ for watermelon; CT = Control (no spray). Means $( \pm \mathrm{SE})$ are values of 4 replications and means ( \pm SE) followed by the same superscript letter(s) within a column are not significantly different using Student-Newman Keul's (SNK) test ( $\mathrm{p} \leq 0.05)$.

Table 5: Effect of Varying Doses of Magicforce ${ }^{\circledR}$ on Yield Related Parameters in Early- and Late-sown Watermelon at Wukari in 2020

\begin{tabular}{lccc}
\hline \multicolumn{1}{c}{ Treatment } & Survival rate (\%) & Number of fruits/ha & $\begin{array}{c}\text { Proportion of fruits } \\
\text { damaged (\%) }\end{array}$ \\
\hline Early-sown & & & \\
HFRD & $92.88 \pm 4.78\left(4.53 \pm 0.05^{\mathrm{a}}\right)$ & $17517.68 \pm 518.95\left(132.31 \pm 1.94^{\mathrm{a}}\right)$ & $3.33 \pm 0.03\left(1.20 \pm 0.01^{\mathrm{d}}\right)$ \\
LFRD & $92.63 \pm 3.62\left(4.53 \pm 0.04^{\mathrm{a}}\right)$ & $16904.23 \pm 701.82\left(129.93 \pm 2.67^{\mathrm{ab}}\right)$ & $4.20 \pm 0.20\left(1.43 \pm 0.05^{\mathrm{c}}\right)$ \\
$2 \mathrm{x}$ HFRD & $86.05 \pm 4.52\left(4.45 \pm 0.05^{\mathrm{a}}\right)$ & $15359.38 \pm 261.34\left(123.92 \pm 1.05^{\mathrm{b}}\right)$ & $3.30 \pm 0.18\left(1.19 \pm 0.05^{\mathrm{d}}\right)$ \\
$1 / 2$ LFRD & $65.53 \pm 1.59\left(4.20 \pm 0.02^{\mathrm{b}}\right)$ & $10390.55 \pm 336.25\left(101.89 \pm 1.63^{\mathrm{c}}\right)$ & $37.28 \pm 1.50\left(3.62 \pm 0.04^{\mathrm{b}}\right)$ \\
CT & $31.43 \pm 3.90\left(3.43 \pm 0.12^{\mathrm{c}}\right)$ & $1367.98 \pm 179.49\left(36.77 \pm 2.32^{\mathrm{d}}\right)$ & $67.15 \pm 1.33\left(4.21 \pm 0.02^{\mathrm{a}}\right)$ \\
P-value & $<0.01$ & $<0.01$ & $<0.01$ \\
Late-sown & & & $4.33 \pm 0.03(1.46 \pm 0.01 \mathrm{c})$ \\
HFRD & $90.73 \pm 5.35\left(4.50 \pm 0.06^{\mathrm{a}}\right)$ & $17167.60 \pm 628.20\left(130.96 \pm 2.38^{\mathrm{a}}\right)$ & $4.78 \pm 0.10(1.56 \pm 0.04 \mathrm{c})$ \\
LFRD & $88.50 \pm 3.62\left(4.48 \pm 0.04^{\mathrm{a}}\right)$ & $16504.20 \pm 742.50\left(128.37 \pm 2.85^{\mathrm{a}}\right)$ & $4.30 \pm 0.18(1.46 \pm 0.08 \mathrm{c})$ \\
2x HFRD & $83.78 \pm 4.71\left(4.42 \pm 0.06^{\mathrm{a}}\right)$ & $14884.38 \pm 289.69\left(121.98 \pm 1.19^{\mathrm{a}}\right)$ & $36.38 \pm 1.88\left(3.59 \pm 0.05^{\mathrm{b}}\right)$ \\
$1 / 2$ LFRD & $57.18 \pm 1.56\left(4.05 \pm 0.03^{\mathrm{b}}\right)$ & $10197.63 \pm 802.18\left(100.75 \pm 4.00^{\mathrm{b}}\right)$ & $72.65 \pm 0.78\left(4.29 \pm 0.01^{\mathrm{a}}\right)$ \\
CT & $28.88 \pm 3.43\left(3.34 \pm 0.11^{\mathrm{c}}\right)$ & $1297.98 \pm 174.96\left(35.80 \pm 2.32^{\mathrm{c}}\right)$ & $<0.01$ \\
P-value & $<0.01$ & $<0.01$ & \\
\hline
\end{tabular}

Figures in parentheses are logarithmic transformed values except, those of number of fruits/ha which is square root transformed; HFRD = Highest Field Recommended Dose of Magicforce ${ }^{\circledR}$ for watermelon; LFRD $=$ Lowest Field Recommended Dose of Magicforce ${ }^{\circledR}$ for watermelon; CT $=$ Control (no spray). Means $( \pm \mathrm{SE}$ ) are values of 4 replications and means $( \pm \mathrm{SE})$ followed by the same superscript letter(s) within a column are not significantly different using StudentNewman Keul's $(\mathrm{SNK})$ test $(\mathrm{p} \leq 0.05)$.

Comparisons of Major Variables between Early- and Late-sown Watermelon and their Relationships

Table 6 shows that student's t-test detected significant $(t \alpha<0.01)$ differences between the early- and late-crops in all the variables tested except in number of leaves/plant at 6 weeks after emergence $(p=0.612)$, number of fruits $/$ ha $(p=$
0.078), and proportion of fruits damaged ( $\mathrm{p}=$ 0.101) in which observed differences were due to random variations. Overall, number of $B$. cucurbitae larvae/fruit, $A$. mellifera density, mean main vine length $(\mathrm{cm})$ at 6 weeks after emergence, and survival rate $(\%)$ were significantly $(t \alpha<0.01)$ higher in the early-sown crops. 
Table 7 shows that the number of fruits/ha exhibited highly negative and significant $(\mathrm{p}<0.01)$ correlation with the number of leaf beetles $/ 5 \mathrm{~m}$ row $\left(r=-0.963, R^{2}=0.927\right)$, proportion of leaves injured $\left(r=-0.902, R^{2}=0.814\right)$, and also severity of leaf injury $\left(r=-0.961, R^{2}=0.924\right)$ in the earlycrops. The relationship between survival rate and leaf beetle density also follows the same pattern ( $\mathrm{r}$ $\left.=-0.920, R^{2}=0.846\right)$. While the number of fruits in the early-crop had weakly positive and insignificant relationship with $A$. mellifera density $\left(r=0.234, R^{2}=0.055, p=0.321\right)$, the number of fruits produced were moderately positive and insignificantly related $\left(\mathrm{r}=0.665, \mathrm{R}^{2}=0.443, \mathrm{p}=\right.$ $0.220)$ with the quantity of Magicforce ${ }^{\circledR}$ applied. In the late-crop, the relationships between the variables followed a trend similar to those of the early-crops.

Table 6: Comparisons between Variables from Early- and Late-sown Watermelon at Wukari

\begin{tabular}{|c|c|c|c|c|c|}
\hline Variables & $\begin{array}{c}\text { Means }( \pm \text { sE) } \\
\text { for early-sown }\end{array}$ & $\begin{array}{c}\text { Means ( } \pm \text { SE) } \\
\text { for late-sown }\end{array}$ & $\begin{array}{c}\text { Means }( \pm \mathrm{sE}) \\
\text { difference }\end{array}$ & t-value & $P$-value \\
\hline Leaf beetles $/ 5 \mathrm{~m}$ length of row & $3.68 \pm 0.76$ & $4.71 \pm 0.87$ & $-1.03 \pm 0.20$ & -5.073 & $<0.01 * *$ \\
\hline B. cucurbitae larvae/fruit & $2.60 \pm 0.51$ & $2.30 \pm 0.49$ & $0.30 \pm 0.07$ & 4.119 & $<0.01 * *$ \\
\hline Predatory ants $/ 5 \mathrm{~m}$ length of row & $3.38 \pm 0.16$ & $3.74 \pm 0.14$ & $-0.36 \pm 0.08$ & -4.404 & $<0.01 * *$ \\
\hline Spiders $/ 5 \mathrm{~m}$ length of row & $2.72 \pm 0.33$ & $3.01 \pm 0.30$ & $-0.30 \pm 0.08$ & -5.659 & $<0.01 * *$ \\
\hline A. mellifera/ $5 \mathrm{~m}$ length of row & $3.18 \pm 0.15$ & $2.83 \pm 0.14$ & $0.35 \pm 0.03$ & 10.899 & $<0.01 * *$ \\
\hline Proportion of leaves injured $(\%)$ & $20.17 \pm 3.80$ & $26.00 \pm 4.63$ & $-5.83 \pm 1.08$ & -5.410 & $<0.01 * *$ \\
\hline Severity of leaves injured $(\%)$ & $12.80 \pm 2.97$ & $14.09 \pm 3.26$ & $-1.30 \pm 0.44$ & -2.904 & $<0.01 * *$ \\
\hline Main vine length at 6 WAE $(\mathrm{cm})$ & $177.24 \pm 10.25$ & $171.64 \pm 10.32$ & $5.60 \pm 1.83$ & 3.049 & $<0.01 * *$ \\
\hline Number of leaves/plant at 6 WAE & $73.67 \pm 6.32$ & $73.03 \pm 6.03$ & $0.64 \pm 1.24$ & 0.515 & $0.612^{\mathrm{ns}}$ \\
\hline Survival rate $(\%)$ & $73.90 \pm 5.56$ & $69.81 \pm 5.67$ & $4.09 \pm 0.72$ & 5.684 & $<0.01 * *$ \\
\hline Number of fruits/ha & $12307.96 \pm 1391.19$ & $12010.38 \pm 1369.62$ & $297.59 \pm 159.91$ & 1.861 & $0.078^{\mathrm{ns}}$ \\
\hline Proportion of fruits damaged $(\%)$ & $23.05 \pm 5.89$ & $24.49 \pm 6.22$ & $-1.44 \pm 0.83$ & -1.724 & $0.101^{\mathrm{ns}}$ \\
\hline
\end{tabular}

$*=$ significantly different $(\mathrm{p} \leqslant 0.05) ; * *=$ significantly different $(\mathrm{p} \leqslant 0.01) ;{ }^{\mathrm{ns}}=$ not significantly different $(\mathrm{p}>0.05)$;

WAE - Weeks after emergence

Table 7: Correlation and Linear Regression Analyses between Leaf Injury Indices, Plant survival, Yield Parameters and Major Watermelon Pests and Beneficials on Early- and Late-sown Crop at Wukari

\begin{tabular}{|c|c|c|c|c|}
\hline Variables & $\begin{array}{c}\text { Correlation } \\
\text { coefficient (r) }\end{array}$ & Regression equation & $\begin{array}{c}\text { Coefficient of } \\
\text { determination }\left(\mathbf{R}^{2}\right)\end{array}$ & $\begin{array}{c}P \text {-value } \\
\text { for } R^{2}\end{array}$ \\
\hline \multicolumn{5}{|l|}{ Early-sown crop } \\
\hline PLI $\times \mathrm{LB} / 5 \mathrm{~m}$ row & 0.953 & $Y=2.646+4.768 x$ & 0.907 & $<0.01 * *$ \\
\hline SLI $x \mathrm{LB} / 5 \mathrm{~m}$ row & 0.987 & $Y=-1.398+3.863 x$ & 0.975 & $<0.01 * *$ \\
\hline $\mathrm{SR} \times \mathrm{LB} / 5 \mathrm{~m}$ row & -0.920 & $Y=98.641-6.732 x$ & 0.846 & $<0.01 * *$ \\
\hline No.F/ha $\times$ LB $/ 5 \mathrm{~m}$ row & -0.963 & $Y=18783.964-1762.178 x$ & 0.927 & $<0.01 * *$ \\
\hline No.F/ha $\mathrm{x} A$. mellifera $/ 5 \mathrm{~m}$ row & 0.234 & $Y=5383.168+2181.037 x$ & 0.055 & $0.321^{\mathrm{ns}}$ \\
\hline PFD x B. cucurbitae/fruit & 0.986 & $Y=-6.657-11.448 x$ & 0.973 & $<0.01 * *$ \\
\hline No.F/ha x Litres of Magicforce ${ }^{\circledR}$ applied/ha & 0.665 & $Y=-1.614+0.001 x$ & 0.443 & $0.220^{\mathrm{ns}}$ \\
\hline No.F/ha x PLI & -0.902 & $Y=18960.314-329.863 x$ & 0.814 & $<0.01 * *$ \\
\hline No.F/ha x SLI & -0.961 & $Y=18063.473-449.737 x$ & 0.924 & $<0.01 * *$ \\
\hline \multicolumn{5}{|l|}{ Late-sown crop } \\
\hline PLI $x \mathrm{LB} / 5 \mathrm{~m}$ row & 0.949 & $Y=2.222+5.051 x$ & 0.901 & $<0.01 * *$ \\
\hline SLI $x \mathrm{LB} / 5 \mathrm{~m}$ row & 0.988 & $Y=-3.514+3.698 x$ & 0.976 & $<0.01 * *$ \\
\hline $\mathrm{SR} \times \mathrm{LB} / 5 \mathrm{~m}$ row & -0.944 & $Y=98.747-6.140 x$ & 0.891 & $<0.01 * *$ \\
\hline No.F/ha $\times \mathrm{LB} / 5 \mathrm{~m}$ row & -0.962 & $Y=19138.998-1514.151 x$ & 0.926 & $<0.01 * *$ \\
\hline No.F/ha $\mathrm{x} A$. mellifera $/ 5 \mathrm{~m}$ row & 0.237 & $Y=5615.593+2261.238 x$ & 0.056 & $0.315^{\mathrm{ns}}$ \\
\hline PFD x B. cucurbitae/fruit & 0.988 & $Y=-4.596+12.644 x$ & 0.976 & $<0.01 * *$ \\
\hline No.F/ha x Litres of Magicforce ${ }^{\circledR}$ applied/ha & 0.659 & $Y=-1.472+0.001 x$ & 0.434 & $0.227^{\mathrm{ns}}$ \\
\hline No.F/ha x PLI & -0.922 & $Y=19101.130-272.721 x$ & 0.850 & $<0.01 * *$ \\
\hline No.F/ha x SLI & -0.962 & $Y=17708.530-404.282 x$ & 0.925 & $<0.01 * *$ \\
\hline
\end{tabular}

PLI - Proportion of leaves injured (\%); LB - Leaf beetles; SLI - Severity of leaf injury (\%); SR - Plant survival (\%); No.F/ha - Number of fruits/ha; PFD - Proportion of fruits damaged $(\%) ; *=$ significantly different $(p \leqslant 0.05) ; * *=$ significantly different $(p \leqslant 0.01){ }^{\text {ns }}=$ not significantly different $(p>0.05)$ 


\section{DISCUSSION}

For decades, the use of synthetic insecticides for pest suppression has resulted in dramatic protection of crops from complete loss leading to rise in yields, better food security, improved livelihood and income for crop growers. However, these achievements unfortunately, did not come without global worries due to disruption of ecosystem processes and even more importantly, toxicity to humans. Hence, the deployment of integrated pest management (IPM) techniques is currently advocated (Vorsah et al., 2020). Given the growing awareness of the nutritional and health benefits of watermelon and hence the rising demand for the fruits, and that it is a very heavily infested crop whose fruits are largely eaten raw (Okrikata and Ogunwolu, 2017), there is need to pay serious attention to pesticide application on it.

Growers of watermelon in Nigeria and particularly, across the southern Guinea Savanna zone rely almost entirely on chemical pesticides, which are largely indiscriminately applied, for pest control as reported by Okrikata and Ogunwolu (2017). To buttress the widespread over-dose of pesticides, a study conducted by Sabur and Molla (2001) shows that more than $20 \%$ of crop growers over-dose their crops with pesticides in Bangladesh. A more recent investigation by Kinuthia (2019) in Kenya showed that $97.7 \%$ of small scale tomato growers over-apply insecticides. Similarly, Jallow et al. (2017) from their study showed that insecticide over-dose by vegetable growers is prevalent in Kuwait due to high infestations. In a study in Ekiti state, Nigeria, Oluwole and Cheke (2009) showed that $94.7 \%$ of crop growers mix 2 or more chemical pesticides and apply on their crops not minding instructions on pesticide labels nor compatibility of the pesticides. Hence, it is not surprising that Hossard et al. (2017) reported that pesticide over-dose is becoming a common feature in contemporary crop production.

The current study not only revealed the high crop loss that is incurred without pesticide intervention on watermelon production, but also confirmed the efficacy of Magicforce ${ }^{\circledR}$ used within the recommended doses. That the recommended doses (highest and lowest) produced more fruits than each of $2 x$ HFRD and $1 / 2$ LFRD treatments, and that the relationship between the quantity of Magicforce $^{\circledR}$ used in this study and the fruits produced though positive, was only moderate and insignificant which highlights the suppressive effects of pesticide over-dose on crop productivity. The observations also highlight the inefficacy/low efficacy of lower than the recommended dose in pest suppressions. Magicforce $^{\circledR}$ used in the current study is a recommended insecticide for the control of watermelon pests; and the formulation contains Lambda-cyhalothrin [a broad spectrum, contact and neurotoxic synthetic pyrethroid] and Dimethoate [a systemic organophosphate which inhibits nerve functions] (NPIC, 2001; Cox, 2002). Its efficacy draws from its suppressive effect of both chewing and sucking pests. The suppressive effect of Magicforce ${ }^{\circledR}$ was observed in the current study as leaf beetle species were suppressed by 1.78 to $8.7 x$, and B. cucurbitae (a fruit eating pest) by 1.67 to $8.57 \mathrm{x}$. Occurrence of sap-sucking pests predominated by aphids and white flies were however sporadic in the current study unlike in the previous studies conducted in the study area in 2016 and 2017 (Okrikata and Ogunwolu, 2019; Okrikata et al., 2020). This may be attributed to unfavourable weather for their colonization of the crops and population growth. The raging effect of climate change has the capacity to modify the behaviour of pests and their hosts. These modifications could draw from phenological and/or physiological changes leading to unstable pest - weather parameter relationships. This gives credit to the postulation that extensive studies are required to establish or model the dynamics of pest populations.

Application of double the highest recommended dose of Magicforce ${ }^{\circledR}$ on the crops effectively suppressed pest densities at levels that were not significantly different from those of the recommended doses. Conversely, halving the lowest recommended dose was ineffective as crops treated with half the lowest recommended dose largely had significantly higher pest densities with 62.5 to $68.3 \%$ lower productivity vis-à-vis the recommended doses. These observations are at variance with the report of Duke (2017) that showed that application of lower than the recommended rates of pesticides can effectively 
manage targeted pests in many cases. Hence, farmers are strongly advised to abide by the manufacturer's recommendations. Abuse of pesticides by way of over- or under-application has been shown to be a leading cause of the evolution of pesticide resistant strains (Gill and Garg, 2014; Kole et al., 2019),

Aside heavy environmental pollution and health safety issues, 2x HFRD was highly uneconomical (monetarily) as it is $2 \mathrm{x}$ more costly than HFRD and $3 x$ than LFRD and overall, its application yielded 1.15 and 1.10x lesser fruit, respectively. A $1.68 \mathrm{x}$ less fruit at $3 \mathrm{x}$ less cost and $1.62 \mathrm{x}$ less fruit at $2 \mathrm{x}$ less cost was however produced by $1 / 2$ LFRD vis-à-vis HFRD and LFRD, respectively. The observed yield trends in the current study hence suggests that the application of the lowest recommended rate of Magicforce ${ }^{\circledR}$ could be more desirable vis-à-vis the highest recommended rate as aside the likelihood of easing environmental pesticide burden and human health issues, it is way more economical with an overall comparatively $50 \%$ less monetary cost for an abysmal $3.8 \%$ less productivity. The foregoing analysis highlights the need to adhere to manufacturer's recommended doses as it favours overall lower production cost for better yield.

As shown by Lamichhane et al. (2016), beneficial arthropods (pollinators, predators and parasitoids) generally tend to be more sensitive to pesticides like synthetic pyrethroids (eg. Deltamethrin and Cypermethrin) and organophosphates (eg. Dimethoate and Malathion) than their pest counterparts. This was clearly observed in the current study as Magicforce $^{\circledR}$ application, particularly 2x HFRD, greatly suppressed densities of beneficial arthropods (spiders, predatory ants and bees - $A$. mellifera). Indiscriminate suppression of beneficial natural enemy species could upset the biological community. Amalin et al. (2009) and Lamichhane et al. (2016) showed that a decrease in population densities of beneficial arthropods such as spiders could lead to pest outbreak.

The role of bees (A. mellifera) in watermelon productivity cannot be overemphasized as optimum fruit setting and development can hardly be achieved without their optimum activity $-\mathrm{a}$ minimum of 8 visits/flower is reported as necessary for good fruit set (Ndor et al., 2012). Plots and/or plants treated with lower than the recommended dose of Magicforce ${ }^{\circledR}(1 / 2$ LFRD) had higher pest densities, leaf damage and also more densities of beneficials (except $A$. mellifera) with a resultant lower growth indices and fruit production than those treated with the recommended doses. Hence, incorrect use of pesticides and or the use of adulterated pesticides can lead to failures in pest control and impede crop productivity.

The current study therefore reveals that, with genuine Magicforce ${ }^{\circledR}$, the perception that some crop growers have, as suggested by the reports of Ojo (2016) and Nemade et al. (2017), that the application of higher than recommended dose of pesticides perform better can be adjudged erroneous as application of $2 \mathrm{x}$ HFRD was neither superior to LFRD nor HFRD in improving growth and productivity of watermelon. However, this erroneous view is largely catalyzed by the availability of adulterated pesticides in open markets in many developing countries as reported by UN, FAO and WHO in their joint report of 2001 where they showed that $30 \%$ of pesticides marketed in developing countries are below international standards (Jeyanthi and Kombairaju, 2005). Hence, there is a need for proper regulation and monitoring of pesticide vendors and also to procure the products from accredited and registered dealers.

In Nigeria, majority of the farmers are illiterate and hence under-dose, but in most cases, overdose crops with pesticides (Oluwole and Cheke, 2009; Ojo, 2016; Nemade et al., 2017; Okrikata and Ogunwolu, 2017). The attendant effect of pesticide over-dose in watermelon is the high pesticide residue in the fruit as reported by Akan $e t$ al. (2015) and Mahmud et al. (2015) in pesticide residue studies conducted in Bade Local Government Area of Yobe State, and also by Omoyajowo et al. (2018) in a similar study conducted in Lagos state.

\section{CONCLUSION}

Despite the significant differences between the early-and late-sown crops in most of the variables assessed as detected by student's t-test, trends 
were largely similar in both seasons. The perception that the application of twice the recommended dose of pesticides will be twice efficacious was observed to be nonfactual with respect to Magicforce ${ }^{\circledR}$ on watermelon. Generally, plots and/or plants treated with higher than the field recommended dose (2x HFRD) of Magicforce $^{\circledR}$ had lower pest (1.11 to $1.35 \mathrm{x}$ lower) and beneficial arthropod (1.23 to $1.47 \mathrm{x}$ lesser) densities with a resultant lower growth indices (1.02 to $1.06 \mathrm{x}$ lower). Additionally, fruit production was 1.10 to $1.15 \mathrm{x}$ lower at 2 to $3 \mathrm{x}$ higher monetary cost. This suggests that application of double the highest field recommended dose of Magicforce ${ }^{\mathbb{B}}$ suppresses the crop growth and also results in lower productivity of the crop - the mechanism of which could be verified in future studies. Crop growers are thus advised to source for genuine pesticides and adhere to the manufacturer's dose recommendations for economic and efficient production.

\section{ACKNOWLEDGEMENTS}

This is an aspect of a Nigerian Government's Tertiary Education Trust Fund) TETFund sponsored research. The authors gratefully acknowledge the management of Federal University, Wukari, Nigeria for providing the platform for accessing the funding with Award letter number: FUW/REG/P.00240/VOL.I. We are also thankful to Mr. Ahmed Mohammed, the technical officer of the research for his uncommon dedication to duty.

\section{REFERENCES}

Agere, H., Okrikata, E., Malu, S.P. and Adepoju, I.O. 2021. Modification of leaf blowervac (Grizzly ELS 2500/8) for sampling arthropods in Watermelon (Citrullus lanatus Thunb.) field. Suan Sunandha Science and Technology Journal, 8(1):27-34.

Akan, J.C., Mahmud, M.M., Waziri, M. and Mohammed Z. 2015. Residues of organochlorine pesticides in watermelon and soil samples from Gashua, Bade LGA, Yobe State, Nigeria. Advances in AnalyticalChemistry, 5(3): 61-68.

Amalin D.M., Peña J.E., Duncan, R., Leavengood, J. and Koptur, S. 2009. Effects of pesticides on the arthropod community in the agricultural areas near the Everglades National Park. Proceedings of Florida State Horticultural Society, 122: 429-437.

Barma, P., Jha, S. and Banerjee, S. 2013. Prediction of population development of melon fruit-fly (Bactrocera cucurbitae Coq.) on pionted gourd (Trichosanthes dioica Roxb.). African Journal of Agricultural Research, 8(38): 4740-4747.

Boedeker, W., Watts, M., Clausing, P. and Marques, E. 2020. The global distribution of acute unintended pesticide poisoning: Estimations based on a systematic review. BMC Public Health, 20: 1875-1894.

Cox, C. 2002. Pyrethrins/pyrethrum insecticide factsheet. Journal of pesticide reform, 22: 1420.

Duke, S.O. 2017. Pesticide dose - A parameter with many implications. In: Pesticide dose: Effects on the environment, target and non-target organisms. Duke, S.O., Kudsk, P. and Solomon, K. (Editors.). ACS Symposium Series, Washington, DC. pp113. DOI: $10.1021 /$ bk-2017-1249.ch001

Gill, H.K. and Garg, H. 2014. Pesticides: Environmental impacts and management strategies. In: Pesticides - Toxic aspects. Larramendy, M.L. and Soloneski, S. (Editors). IntechOpen. Pp. 187-230. DOI: 10.5772/57399

Glover-Amengor, M. and Tetteh, F.M. 2008. Effect of pesticide application rate on yield of vegetables and soil microbial communities. West African Journal of Applied Ecology, 12:1-7.

Hossard, L., Philibert, A. Bertraad, M., Colnennedavid, C., Debaeke, P., Munier-Jolain, N., Jeuffroy, M.H., Richard, G. and Mokowski, D. 2014. Effects of halving pesticide use on wheat production. Science Reports, 4(4405): 1-7.

Hossard, L., Guichard, L., Pelosi, C. and Makowski, D. 2017. Lack of evidence for a decrease in synthetic pesticide use on the main arable crops in France. Science of the Total Environment, 575: 152-161.

Jallow, M.F.A., Awadh, D.G., Albaho, M.S., Devi, V.Y. and Thomas, B.M. 2017. Pesticide risk behaviours and factors influencing pesticide use among farmers in Kuwait. Science of the Total Environment, 574: 
490-498.

Jeyakumar, P. and Gupta, G.P. 2002. Utilization of neem and $B t$ for managing bollworms in cotton. Indian Journal of Entomology, 64: 424-433.

Jeyanthi, H. and Kombairaju, S. 2005. Pesticide use in vegetable crops: frequency, intensity and determinant factors. Agricultural Economics Research Review, 18: 209-221.

Kinuthia C.W. 2019. Determinants of pesticide use and uptake of alternative pestcontrol methods among small scale tomato farmers in Nakuru County, Kenya. M.Sc. Thesis, Egerton University, 102pp.

Kole, R.K., Roy, K., Panja, B.N., Sakarganesh, E., Mandal, T. and Worede, R.E. 2019. Use of pesticide in Agriculture and emergence of resistant pests. Indian Journal of Animal Health, 58(2): 53-70.

Kranthi, K.R., Jadhau, D.R., Wanjari, R.R., Ali, S. and Russell, D. 2002. Insecticide resistance in five major insect pests of cotton in India. Crop Protection, 21: 449460.

Lamichhane, J.R., Dachbrodt-Saaydeh, S., Kudsk, P. and Messean, A. 2016. Toward a reduced reliance on conventional pesticides in European Agriculture, Plant Disease, 100(1): 10-24.

Mahmud, M.M., Akan J.C., Mohammed, Z. and Battah, N. 2015. Assessment of organophosphorus and pyrethroid pesticide residues in watermelon and soil samples from Gashua, Bade LGA, Yobe State, Nigeria. Journal of Environment, Pollution and Human Health, 3(3): 52-61.

Meena, R.S., Kumar, S., Datta, R., Lal, R., Vijayakumar, V., Brtnicky, M., Sharma, M.P., Yadav, G.S., Jhariya, M.K., Jangir, C.K., Pathan, S.I., Dokulilova, T., Pecina, V. and Marfor, T.D. 2020. Impact of agrochemicals on soil microbiota and management: a review. Land, 9:34-55.

Ndor, E., Dauda, S.N., Anda, D., Chamang, H.B. and Farringoro, U.D. 2012. Assessing the efficacy of aqueous leaf extract of some botanicals for control of field insects of watermelon (Citrullus lanatus) in Southern Guinea Savanna, Nigeria. Asian Journal of Agricultural Science, 4(5): 329-332.

Nemade, P.W., Wadaskar, R.M., Ughade, J., Sable,
Y.R. and Rathod, T.H. 2017. Validation of recommended doses of insecticides against sucking pests of $B t$ cotton. Journal of Entomology and Zoology Studies, 5(3): 256260.

NPIC (National Pesticide Information Centre) 2001. Lambda-cyhalothrin general factsheets. Oregon State University and the U.S. Environmental Protection Agency. 6pp.

Ojo, J. (2016). Pesticides use and health in Nigeria. Ife Journal of Science, 18(4): 981-991.

Okrikata, E. and Anaso, C.E. 2008. Influence of some inert diluents of neem kernel powder on protection of sorghum against pink stalk borer (Sesamia calamistis Homps.) in Nigerian Sudan Savanna. Journal of Plant Protection Research, 48(2): 161-168.

Okrikata, E. and Ogunwolu, E.O. 2017. Farmers' perceptions on arthropod pests of watermelon and their management practices in the Nigerian Southern Guinea Savanna. International Journal of Agricultural Research, 12(4): 146-155.

Okrikata, E. and Ogunwolu, E.O. 2019. Determination of the critical period of cyper-diforce $^{\circledR}$ treatment against arthropod fauna and productivity of Watermelon. Iraqi Journal of Science, 60(9): 1904-1919.

Okrikata, E., Ogunwolu, E.O. and Ukwela, M.U. 2019a. Diversity, spatial and temporal distribution of above-ground arthropods associated with Watermelon in the Nigerian Southern Guinea Savanna. Journal of Insect Biodiversity and Systematics, $5(1): 11-32$.

Okrikata, E., Ogunwolu, E.O. and Ukwela, M.U. 2019b. Efficiency and economic viability of neem seed oil emulsion and cyperdiforce $^{\circledR}$ insecticides in Watermelon production within the Nigerian Southern Guinea Savanna Zone. Journal of Crop Protection, 8(1): 81-101.

Okrikata, E., Ogunwolu, E.O. and Odiaka, N.I. 2020. Effect of cyper-diforce ${ }^{\circledR}$ application and variety on major insect pests of watermelon in the Southern Guinea Savanna of Nigeria. Jordan Journal of Biological Sciences, 13(1): 107-115. 
Oluwole, O. and Cheke, R.A. 2009. Health and environmental impacts of pesticide use practices: a case study of farmers in Ekiti State, Nigeria. International Journal of Agricultural Sustainability, 7(3): 153-163.

Omoyajowo, K., Njok, K., Amiolemen, S., Ogidan, J., Adenekan, O., Olaniyan K., Akande, J. and Idowu, I. 2018. Assessment of pesticide residue levels in common fruits consumed in Lagos State, Nigeria. Journal of Research and Reviews in Science, 1 : $56-62$.

Reetu, V. and Tomar, M. 2017. Watermelon: A valuable horticultural crop with nutritional benefits. Popular Kheti, 5(2): 5-9.
Sabur, S.A. and Molla, A.R. 2001. Pesticide use, its impact on crop production and evaluation of IPM technologies in Bangladesh. Bangladesh Journal of Agricultural Economics, 24(1\&2):21-38.

Shagufta, S. (2012). Fruits and vegetables production. African Publishing House, Ibadan, Nigeria. 420pp.

Vorsah, R.V., Dingha, B.N., and Sharma, H. and Jackai, L.E. 2020. Evaluation of biorational insecticides as stand-alone treatments for the management of the pigweed flea beetle, Disonychia glabrata (Coleoptera: Chrysomelidae) in organic production of Amaranthus spp. Sustainable Agriculture Research, 9(3): 58-70. 